\title{
Use and efficacy of low-dose ketamine in the management of acute postoperative pain: a review of current techniques and outcomes
}

\author{
Roger L. Schmid ${ }^{\mathrm{a}, 1}$, Alan N. Sandler ${ }^{\mathrm{a}, \mathrm{b}}$, Joel Katz ${ }^{\mathrm{a}, \mathrm{b}, \mathrm{c}, *}$ \\ ${ }^{a}$ Acute Pain Research Unit, Department of Anaesthesia, The Toronto Hospital and Mount Sinai Hospital, Toronto, Ontario, Canada \\ ${ }^{\mathrm{b}}$ Department of Anaesthesia, University of Toronto, Toronto, Ontario, Canada \\ 'Department of Public Health Sciences, University of Toronto, Toronto, Ontario, Canada
}

\begin{abstract}
Ketamine hydrochloride is a well known general anesthetic and short acting analgesic in use for almost 3 decades. The role of the NMDA receptor in the processing of nociceptive input has led naturally to renewed clinical interest in $N$-methyl-D-aspartate (NMDA) receptor antagonists such as ketamine. This paper reviews the use and efficacy of low-dose ketamine in the management of acute postoperative pain. The literature was obtained from a computer search of the MEDLINE ${ }^{\circledR}$ database from 1966 through December 1998. Studies were included for review if they were randomized, prospective, controlled, double-blind and reported pain scores. We evaluate the clinical literature and discuss the efficacy of low-dose ketamine in the management of acute postoperative pain when administered alone or in conjunction with other agents via the oral, intramuscular, subcutaneous, intravenous and intraspinal routes. Low-dose ketamine is defined as a bolus dose of less than $2 \mathrm{mg} / \mathrm{g}$ when given intramuscularly or less than $1 \mathrm{mg} / \mathrm{kg}$ when administered via the intravenous or epidural route. For continuous i.v. administration low-dose ketamine is defined as a rate of $\leq 20 \mu \mathrm{g} / \mathrm{kg}$ per min. We conclude that ketamine may provide clinicians with a tool to improve postoperative pain management and to reduce opioid related adverse effects. The evidence suggests that low-dose ketamine may play an important role in postoperative pain management when used as an adjunct to local anesthetics, opioids, or other analgesic agents. Further research is required in the following areas: (a) dose-finding studies for ketamine as an adjunct to opioids and local anesthetics (b) efficacy and optimal route of administration (c) the role of $S(+)$-ketamine; (d) the influence of ketamine on long-term outcome such as chronic pain (e) long-term physical and chemical stability of mixtures containing ketamine (f) spinal toxicity of ketamine and (g) effects of low-dose ketamine on cognitive and memory functioning after surgery. (C) 1999 International Association for the Study of Pain. Published by Elsevier Science B.V.
\end{abstract}

Keywords: Ketamine; Postoperative Pain; Pharmacodynamics

\section{Introduction}

A variety of substances and modalities are currently in use for the management of postoperative pain. To optimize pain management and outcome there is a continuous search for new analgesics and alternative routes of delivery. Ketamine is a well known general anesthetic and short acting analgesic in use for almost 3 decades. The recent discovery of the $N$-methyl-D-aspartate (NMDA) receptor (Foster and Fagg, 1987) and its links to pain processing and spinal neural plasticity triggered renewed interest in ketamine as

\footnotetext{
* Corresponding author. Department of Psychology, Toronto General Hospital, 200 Elizabeth Street, CW 2-318, Toronto, ON M5G 2C4, Canada. Tel.: + 1-416-340-3777; fax: + 1-416-340-4739.

E-mail address: j.katz@utoronto.ca (J. Katz)

${ }^{1}$ Present address: An der Vogelweide 51, D-53229 Bonn, Germany.
}

a potential anti-hyperalgesic agent (Wilcox, 1991) given its actions as a non-competitive NMDA-receptor antagonist.

Ketamine has found a niche as a general anesthetic agent for various procedures in anesthesia and emergency medicine. Its usefulness, however, has been limited by its undesirable psychic emergence effects and cardiovascular stimulating properties. It therefore, remains a controversial drug to many anesthetists who remain wary of its adverse effects. However, it is becoming increasingly clear that a distinction must be made between the use of high-dose ketamine as an anesthetic agent and the use of low-dose ketamine for analgesic or anti-hyperalgesic effects. There may even be a third dose range in which ketamine has no analgesic potency on its own but when used in combination with an opioid, yields an opioid sparing effect and superior pain relief than either drug alone (Chapman and Dickenson, 1992; Dickenson, 1993). 
In this review we briefly summarize the pharmacology of ketamine. We then evaluate and discuss the effectiveness and usefulness of low-dose ketamine in its different modes of application in the management of postoperative pain. Finally, we offer clinical recommendations and suggestions for future research.

For the purpose of the present review, low-dose ketamine is defined as a bolus dose of less than $2 \mathrm{mg} / \mathrm{kg}$ when given intramuscularly or less than $1 \mathrm{mg} / \mathrm{kg}$ when administered via the intravenous or epidural route. For continuous i.v. administration low-dose ketamine is defined as a rate of $\leq 20 \mu \mathrm{g} /$ $\mathrm{kg}$ per min.

\section{Pharmacology}

Ketamine (CI-581, Ketalar $\left.^{(}\right)$was developed in a search for an 'ideal' anesthetic. Ketamine was first synthesized by Stevens (1963) as a further development of phencyclidine and its congener cyclohexamine and was approved for clinical use in 1970. The ketamine molecule 2-(o-chlorophenyl)-2-(methylamino) cyclohexanone has a molecular weight of 238 (Silvay, 1983), is soluble in water to $20 \%$ (Corssen and Domino, 1966), and has a $p \mathrm{~K}_{\mathrm{a}}$ of 7.5 (Cohen and Trevor, 1974). The aqueous solutions of ketamine hydrochloride in clinical use have a $\mathrm{pH}$ range from 3.5 to 5.5. Under physiologic conditions the uncharged form of ketamine is highly lipid soluble (10 times that of thiopentone (Reich and Silvay, 1989)). It is available as a racemic mixture that contains equal amounts of the two isomers $\mathrm{S}(+)$-ketamine and $\mathrm{R}(-)$-ketamine. In both animals and humans $\mathrm{S}(+)$-ketamine is $3-4$ times more potent than $\mathrm{R}(-)$-ketamine for pain relief (Marietta et al., 1977; Ryder et al., 1978; White et al., 1985; Oye et al., 1992; Mathisen et al., 1995;) and in equianalgesic doses, produces fewer psychic disturbances and less agitation than $\mathrm{R}(-)$ ketamine or the racemate (Marietta et al., 1977; Ryder et al., 1978; White et aI., 1980; Calvey, 1995) but see (Schuttler, 1992; Mathisen et al., 1995).

\subsection{Pharmacodynamics}

Ketamine acts on a variety of receptors, including nicotinic (Scheller et al., 1996) and muscarinic (Hustveit et al., 1995) receptors. Ketamine blocks peripheral and human central nervous system sodium channels (Scheller et al., 1996), it interacts with mu $(\mu)$, delta $(\delta)$, and kappa $(\kappa)$ opioid receptors (Smith et al., 1980; Finck and Ngai, 1982; Hustveit et al., 1995) and interacts with monoaminergic and voltage sensitive $\mathrm{Ca}^{++}$channels (Hirota and Lambert, 1996). Ketamine also acts as a non-competitive antagonist (see below) at the phencyclidine receptor site in the NMDA receptor complex channel (Willetts et al., 1990; Yamamura et al., 1990).

The role of the NMDA receptor in the processing of nociceptive input led naturally to renewed clinical interest in NMDA receptor antagonists such as ketamine (Ilkjaer et al., 1996). Low-dose ketamine induces a use-dependent, non-competitive blockade (Dickenson, 1995), also referred to as an 'uncompetitive blockade' (Rogawski, 1993; Orser et al., 1997), meaning that the rate of onset and recovery of the block depends on agonist binding at a different receptor site. This implies that the receptor channel has to be in the open state before ketamine can bind to or dissociate from the blocking site presumed to be situated within the channel pore (Orser et al., 1997). This raises the possibility that ketamine can become 'trapped' in the receptor channel until the channel reopens after agonist activation (Foster and Fagg, 1987). A second NMDA receptor binding site for ketamine has been reported that is associated with the hydrophobic domain of the protein (Orser et al., 1997). Binding at the former receptor site (in the channel) decreases channel open time, whereas binding at the latter site decreases the frequency of channel opening.

\section{Use of ketamine for postoperative pain management}

\subsection{Data identification}

The literature referenced in this review was obtained from a computer search of the MEDLINE ${ }^{\circledR}$ database from 1966 through December 1998.

Of the 50 studies identified, those publications which fulfilled the following criteria were chosen for in depth analysis and discussion: randomized, prospective, controlled, double-blind and reporting pain scores. A total of 28 publications $(56 \%)$ met the above criteria. The 22 $(44 \%)$ remaining studies which did not fulfill these criteria are identified in Table 1 without additional comment. Due to the different study objectives and study designs, a metaanalysis of the published data was not deemed appropriate.

\section{Routes of administration}

In this section, we describe the different routes of ketamine administration in the treatment of postoperative pain. This is followed by a brief summary of outcomes based on the studies that fulfill the above stated criteria.

\subsection{Oral, rectal and intranasal ketamine}

The oral, rectal, and intranasal routes of administration of ketamine have been evaluated extensively to provide premedication for general anesthesia (Weksler et al., 1993; Alderson and Lerman, 1994; Warner et al., 1995; Cioaca and Canavea, 1996) or sedation for a variety of surgical procedures (Abrams et al., 1993; Alfonzo-Echeverri et al., 1993; Louon and Reddy, 1994). The analgesic efficacy of oral ketamine has only been examined in children requiring laceration repair (Hollman and Perloff, 1995). The analgesic effects of oral, rectal and intranasal ketamine in the postoperative setting either as an adjunct 
Table 1

Studies not fulfilling inclusion criteria ${ }^{a}$

\begin{tabular}{lll}
\hline Author and year & Route & Criteria not fulfilled \\
\hline Mathisen et al., (1995) & i.m. & R, C, DB \\
Bristow and Orlikowski (1989) & s.c. & DB, P \\
Ito and Ichiyanagi (1974) & i.v. & R, C, DB,P \\
Austin (1981) & i.v. & R, C, DB \\
Dick et al., (1983) & i.v. & C, DB \\
Knoche et al. (1983) & i.v. & C, DB \\
Forestner (1988) & i.v. & R, C, DB, P \\
Hartvig et al. (1993) & i.v. & R, C, DB, P \\
Islas et al. (1985) & Epidural & R, C, DB \\
Chung et al. (1986) & Epidural & R, C, DB \\
Naguib et al. (1986) & Epidural & C, DB \\
Ravat et al. (1987) & Epidural & C, DB \\
Kawana et al. (1987) & Epidural & P \\
Jiang et al. (1988) & Epidural & DB \\
Naguib et al. (1991) & Epidural & C, DB \\
Cook et al. (1995) & Epidural & DB, P \\
Semple et al. (1996) & Epidural & DB, P \\
Yanli and Eren (1996) & Epidural & P \\
Kucuk et al. (1998) & Epidural & DB \\
Weir and Fee (1998) & Epidural & P \\
Findlow et al. (1997) & Epidural & C, DB, P \\
\hline
\end{tabular}

${ }^{\mathrm{a}} \mathrm{R}$, randomized; $\mathrm{C}$, controlled; $\mathrm{DB}$, double-blind; $\mathrm{P}$, patient-rated pain.

to opioid analgesia or as the sole agent have not been determined.

\subsection{Intramuscular ketamine}

Ketamine is rapidly absorbed after intramuscular injection with an absorption half life of 2-17 min. After injection it appears in the plasma in less than $4 \mathrm{~min}(=$ lag time) and has a bioavailability of $93 \%$. The mean \pm SE terminal plasma half life is $155 \pm 12 \mathrm{~min}$ (Clements and Nimmo, 1981).

A variety of doses have been administered ranging from $0.44 \mathrm{mg} / \mathrm{kg}$ (Sadove et al., 1971; Parkhouse and Marriott, 1977) to $1.0 \mathrm{mg} / \mathrm{kg}$ (Dich-Nielsen et al., 1992) (Table 2). Ketamine has been given as a single bolus injection (Sadove et al., 1971; Parkhouse and Marriott, 1977; Hagelin and Lundberg, 1981; Mathisen et al., 1995) or on demand (Dich-Nielsen et al., 1992) to patients undergoing a variety of surgical procedures (e.g. abdominal surgery, orthopedic surgery, thoracic surgery and orofacial surgery). Intramuscular ketamine has been administered as a sole analgesic agent (Sadove et al., 1971; Mathisen et al., 1995) or in combination with meperidine (Parkhouse and Marriott, 1977; Hagelin and Lundberg, 1981; Dich-Nielsen et al., 1992).

The results of these studies indicate that an intramuscular bolus of ketamine alone $(0.5-1.0 \mathrm{mg} / \mathrm{kg})$ is effective with a 1-2 fold analgesic potency $(\mathrm{mg} / \mathrm{mg})$ of that of i.m. pethidine. Most studies involved only single injections. Pain relief was rapid in onset (within $5 \mathrm{~min}$ ) and lasted from $0.5 \mathrm{~h}$ (Sadove et al., 1971) to $2 \mathrm{~h}$ (Hagelin and Lundberg, 1981). Combining ketamine with an opioid may prolong analgesia compared with opioids or ketamine alone (Parkhouse and Marriott, 1977). Low-dose intramuscular ketamine $(0.5-1 \mathrm{mg} / \mathrm{kg})$ does not appear to have hemodynamic or respiratory depressant effects (Hagelin and Lundberg, 1981; Dich-Nielsen et al., 1992). Sedation, psychotomimetic effects and other adverse reactions associated with low-dose i.m. ketamine are infrequent and doserelated (see Table 2).

\subsection{Subcutaneous ketamine}

Subcutaneous (s.c.) administration of drugs has the potential advantage of relatively even and slow absorption into the bloodstream (Schwinn et al., 1994). This prevents high peak blood levels that occur after intravenous bolus administration. Low-dose $(1.7 \mu \mathrm{g} / \mathrm{kg}$ per min) s.c. ketamine administered after major abdominal surgery did not produce adverse effects and provided postoperative analgesia equivalent to a s.c. morphine infusion of $2 \mathrm{mg} / \mathrm{h}$ (Bhattacharya et al., 1994).

\subsection{Intravenous ketamine}

Ketamine is distributed rapidly after intravenous administration with a bioavailability of $93 \%$ (Grant et al., 1981). Thereafter, plasma levels fall rapidly; however, the mean terminal half life is $186 \pm 10$ min fitting a two compartment open model (Clements and Nimmo, 1981). The studies using i.v. ketamine have heterogeneous designs (Table 3). Ketamine has been administered as either a single bolus injection (Maurset et al., 1989; Ngan Kee et al., 1997), bolus injection followed by a continuous infusion (Joachimsson et al., 1986; Owen et al., 1987; Jahangir et al., 1993), continuous infusion (Clausen et al., 1975), continuous infusion combined with either an opioid or a benzodiazepine (Edwards et al., 1993; Jahangir et al., 1993; Stubhaug et al., 1997; Wilder-Smith et al., 1998), or via a patient-controlled device (PCA) (Javery et al., 1996). In some studies opioid rescue medication was made available to patients. Studies in Table 3 can be categorized as follows: bolus injection, bolus injection plus continuous infusion, continuous infusion, or patient-controlled.

Taken together these studies suggest that analgesic efficacy of i.v. ketamine depends on infusion rate, initial loading dose and whether concomitant opioids are administered (Table 4). Ketamine produces effective but short acting pain relief when administered as a single bolus of $>300 \mu \mathrm{g} / \mathrm{kg}$ (Maurset et al., 1989). Ketamine does not have any effect on postoperative pain or morphine consumption when administered (without a loading dose) as a continuous infusion of less than $4 \mu \mathrm{g} / \mathrm{kg}$ per min (Edwards et al., 1993). In combination with a loading dose however, ketamine infusion rates of $1-6 \mu \mathrm{g} / \mathrm{kg}$ per min provide evidence of anti-hyperalgesic, analgesic and opioid sparing effects (Owen et al., 1987; Jahangir et al., 1993; Stubhaug et al., 1997). At higher doses, ketamine appears to provide an equivalent degree of postoperative pain relief as do opioids, but onset can be 


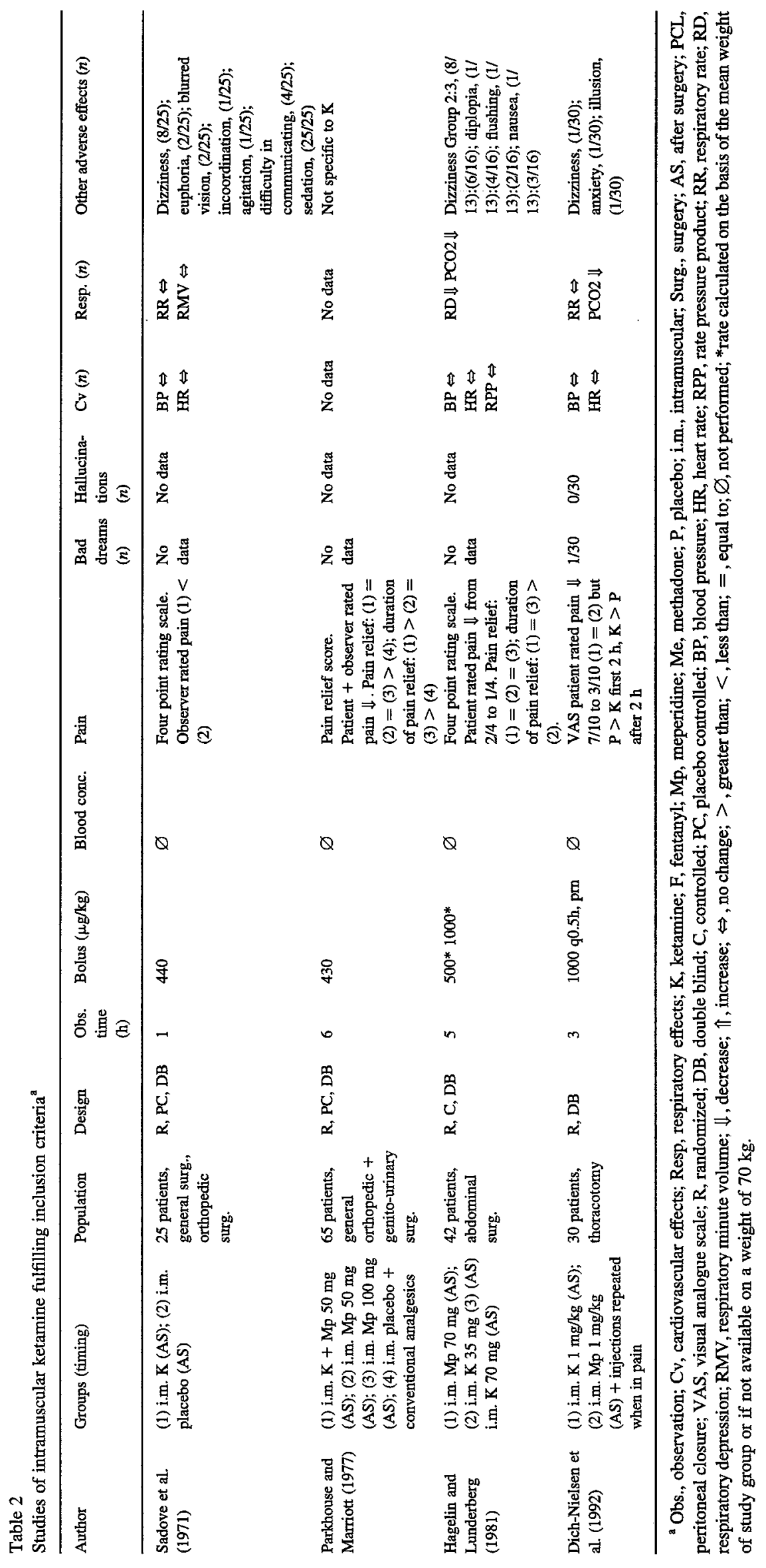




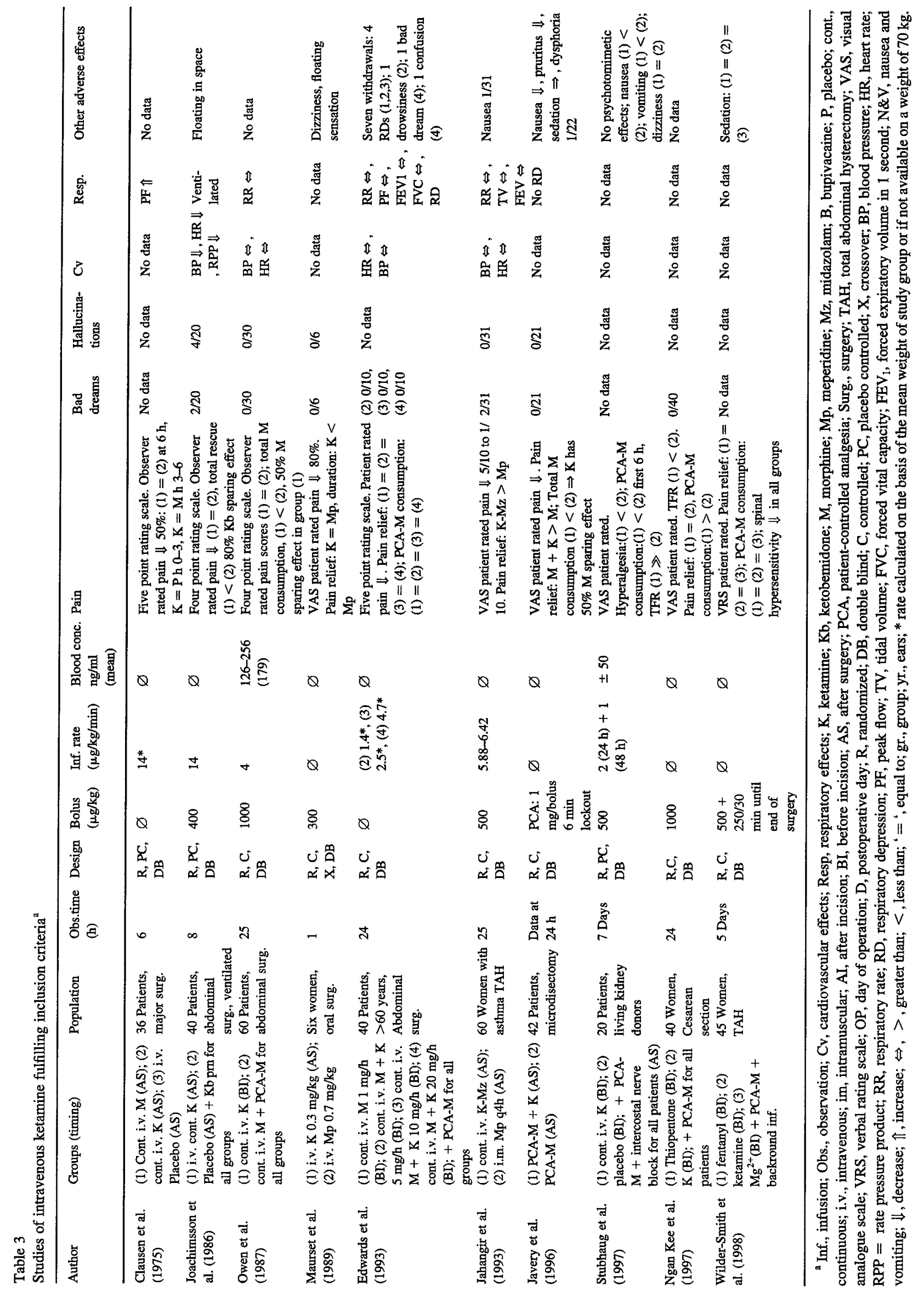


Analgesic efficacy of intravenous ketamine with or without bolus administration or concomitant opioids

\begin{tabular}{|c|c|c|c|c|c|}
\hline \multirow[t]{2}{*}{ Reference } & \multicolumn{3}{|l|}{ Ketamine regime } & \multicolumn{2}{|l|}{ Outcome } \\
\hline & Infusion $(\mu \mathrm{g} / \mathrm{kg}$ per min) & Bolus $(\mu \mathrm{g} / \mathrm{kg})$ & Concomitant opioid & Analgesic effect & Opioid sparing effect \\
\hline Maurset et al. (1989) & No & 300 & No & Yes & - \\
\hline Javery et al. (1996) & No & 14 & Yes & $?$ & Yes \\
\hline Wilder-Smith et al. (1998) & No & $500 / 250$ & Yes & $\mathrm{Yes}^{\mathrm{a}}$ & No \\
\hline Edwards et al. (1993) & $<4$ & No & Yes & No & No \\
\hline Stubhaug et al. (1997) & $1-2$ & 500 & Yes & $\mathrm{Yes}^{\mathrm{b}}$ & Yes \\
\hline Owen et al. (1987) & 4 & 1000 & Yes & Yes & Yes \\
\hline Jahangir et al. (1993) & 6 & 500 & No & Yes & - \\
\hline Clausen et al. (1975) & 14 & No & No & Yes & - \\
\hline Joachimsson et al. (1986) & 14 & 500 & Yes & Yes & Yes \\
\hline
\end{tabular}

${ }^{\mathrm{a}}$ Anti-hyperalgesic.

${ }^{\mathrm{b}}$ Anti-hyperalgesic and analgesic $(6 \mathrm{~h})$.

delayed by several hours if a loading dose is not also administered. A value for the analgesic potency of ketamine alone cannot be calculated from the available studies.

Low-dose i.v. ketamine is a potent and safe adjunct to systemic opioid analgesia. When ketamine $(1.0-14.0 \mu \mathrm{g} / \mathrm{kg}$ per-min following a loading dose) is combined with opioid administration, the combination is associated with better pain relief and an opioid-sparing effect as large as $50 \%$. When compared with opioids alone, the PCA opioid-sparing effect of ketamine is evident even at minimal bolus doses (e.g. $14.0 \mu \mathrm{g} / \mathrm{kg}$ i.v. ketamine) (Javery et al., 1996). At the doses reported above, ketamine has not been found to cause any significant cardiovascular or respiratory effects. Sedation, dreams, hallucinations and other psychotomimetic adverse reactions are infrequent and the incidence increases with dose.

\subsection{Intraspinal ketamine}

Intraspinal techniques include caudal ketamine or caudal ketamine with local anesthetics, lumbar epidural ketamine, lumbar epidural ketamine with local anesthetics and/or opioids and thoracic epidural ketamine with opioids. Ketamine is rapidly absorbed from the epidural space into the systemic circulation with a mean bioavailability $( \pm \mathrm{SD})$ of $77 \pm 22 \%$. However, slow release from the CSF results in decreased levels of metabolites (Pedraz et al., 1987).

Animal studies have demonstrated the safety of intrathecal $1 \%$ ketamine with preservative after a single dose (Brock-Utne et al., 1982) and for ketamine without preservative after multiple doses (Borgbjerg et al., 1994). However, both the preservative itself (Malinovsky et al., 1993) and preservative-free (Yaksh, 1996) ketamine may induce spinal toxicity and therefore, should not be injected intraspinally in humans. It should be noted that ketamine has not been licensed for epidural administration anywhere in the world.

Case reports, comments and studies of epidural ketamine are numerous (Mankowitz et al., 1982; Amiot et al., 1985; Islas et al., 1985; Ivankovich and McCarthy, 1986; Naguib et al., 1986; Kawana et al., 1987; Ravat et al., 1987; Van der Auwera et al., 1987; Naguib and Adu-Gyamfi, 1988). However, excluding studies in which ketamine is administered pre-emptively (described below), there are only three controlled clinical studies (Table 5) in which the efficacy of epidural ketamine has been assessed. These studies indicate that epidural ketamine as the sole agent does not provide effective postoperative analgesia (Peat et al., 1989; Wong et al., 1997). In combination with epidural morphine, low-dose ketamine exerts an opioid-sparing effect and provides improved pain relief compared with epidural morphine alone (Wong et al., 1997; Chia et al., 1998).

\section{Preemptive ketamine}

The rationale for preemptive analgesia in the management of postoperative pain has been reviewed in detail (Katz et al., 1992; Coderre et al., 1993; Dahl and Kehlet, 1993; Woolf and Chong, 1993; Katz, 1995). Since ketamine is an NMDA-receptor antagonist, it is hypothesized to prevent or reverse (already established) central sensitization and thus to reduce postoperative pain. Initial results using ketamine preemptively are encouraging. Studies investigating preemptive analgesic effects of ketamine fall into two groups depending on the route of administration; either i.v. or epidural (Table 6).

Low-dose ketamine administered i.v. (Murray et al., 1987; Roytblat et al., 1993; Tverskoy et al., 1994; Fu et al., 1997) or via the epidural route (Choe et al., 1997; Wong et al., 1997; Abdel-Ghaffar et al., 1998) resulted in reduced postoperative pain intensity and/or analgesic consumption. This appears to be the case whether ketamine is given in conjunction with an opioid or a local anesthetic or as the sole agent. 


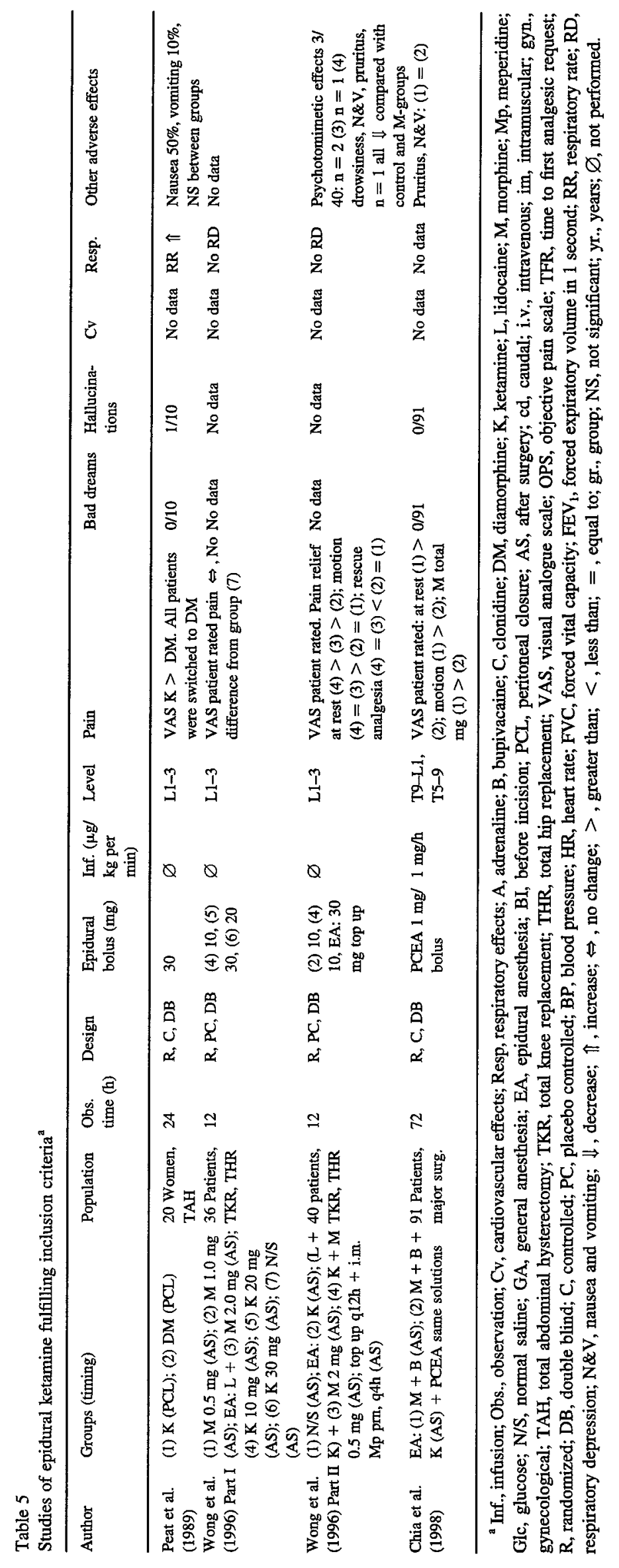




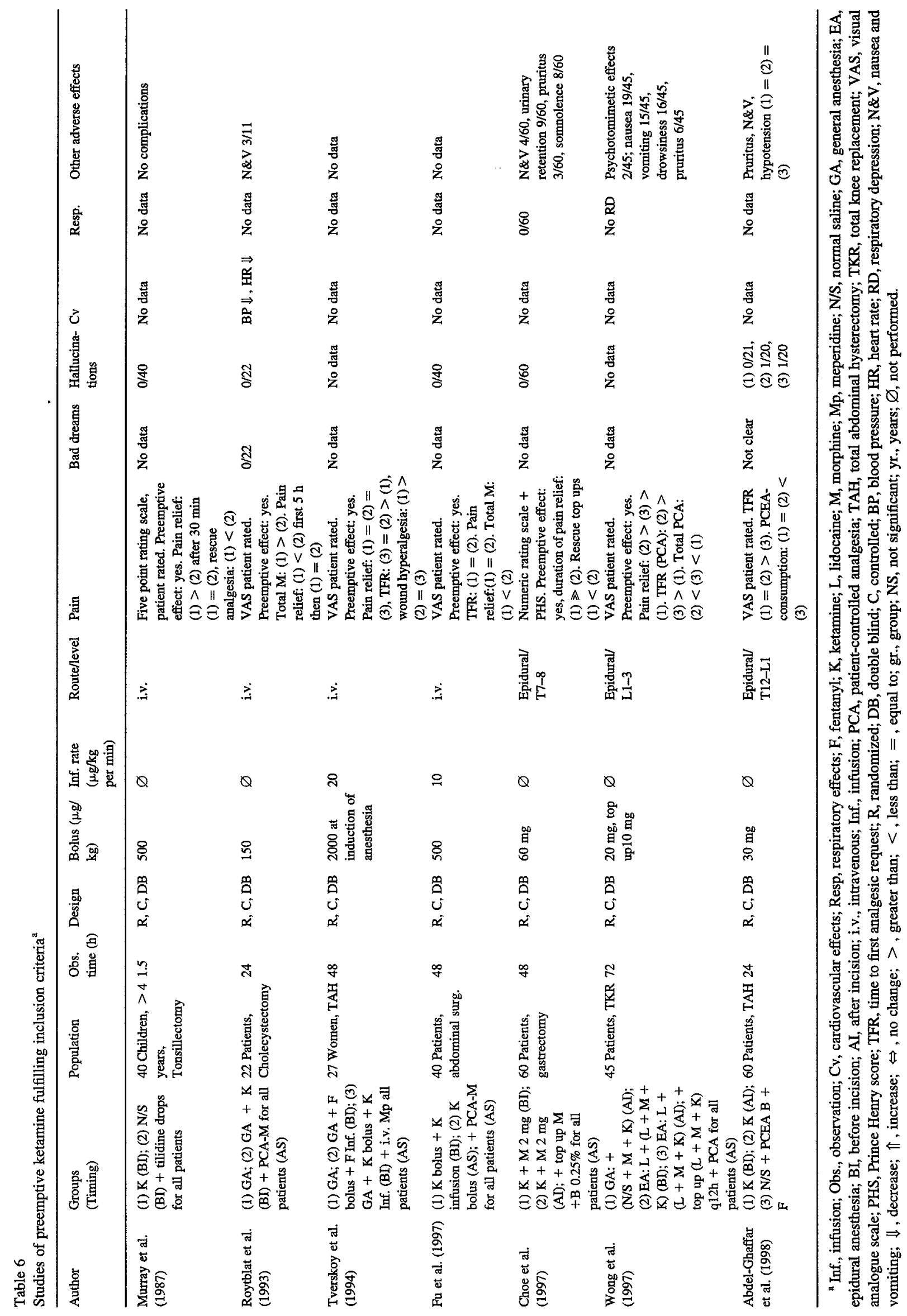




\section{Miscellaneous}

In this section we summarize the studies that could not be categorized under one of the above headings.

The postoperative analgesic effects of preoperatively administered i.v. ketamine $(0.2 \mathrm{mg} / \mathrm{kg})$ or i.v. fentanyl (1 $\mu \mathrm{g} / \mathrm{kg}$ ) were evaluated followed by administration of bupivacaine or i.t. neostigmine and bupivacaine (Lauretti and Azevedo, 1996) (Table 7). Co-administration of ketamine with intrathecal neostigmine showed a clear and prolonged postoperative analgesic effect.

Tverskoy et al. (1996) compared the analgesic effects of wound infiltration after herniorrhaphy using a mixture of bupivacaine $(0.5 \%)$ and ketamine $(0.35 \%)$ or bupivacaine alone $(0.5 \%)$. Addition of ketamine enhanced both the local anesthetic and analgesic effects of bupivacaine wound infiltration. Similar findings were also reported in which ketamine and bupivacaine or bupivacaine alone was infiltrated into the wound at the end of surgery. A peripheral mechanism of action of ketamine is suggested by these investigators.

\section{Pharmacologic effects}

Postoperative pain management is usually limited by adverse effects. In this section, we briefly summarize the pharmacological effects of low-dose ketamine on respiration, cardiovascular function, sedation, nausea and vomiting, urinary retention, constipation/prolonged adynamic postoperative ileus and psychological function. There is no evidence to indicate that low-dose ketamine (up to 1 $\mathrm{mg} / \mathrm{kg}$ ) causes or contributes to respiratory depression (Maduska and Hajghassemali, 1978; White et al., 1982; Bourke et al., 1987; Owen et al., 1987; Peat et al., 1989; Edwards et al., 1993; Jahangir et al., 1993; Bhattacharya et al., 1994).

Studies examining cardiovascular response to low-dose ketamine report minimal changes in heart rate and blood pressure (Sadove et al., 1971; Hagelin and Lundberg, 1981; Owen et al., 1987; Dich-Nielsen et al., 1992; Edwards et al., 1993; Jahangir et al., 1993; Bhattacharya et al., 1994). Two studies (Joachimsson et al., 1986; Roytblat et al., 1993) found a decrease in heart rate and blood pressure which was attributed to a decrease in pain.

Low-dose ketamine may cause mild sedation (Sadove et al., 1971) that is less than the sedation seen with opioids (Bristow and Orlikowski, 1989; Bhattacharya et al., 1994). In combination with opioids, low-dose ketamine does not appear to aggravate or contribute to opioid-induced sedation (Javery et al., 1996; Stubhaug et al., 1997).

Clinical studies have not investigated the emetic or antiemetic effects of low-dose ketamine. However, when lowdose ketamine was used alone or in conjunction with an opioid in the treatment of postoperative pain, the incidence of postoperative nausea and vomiting was significantly reduced compared with morphine alone (Bhattacharya et al., 1994; Gurnani et al., 1996; Javery et al., 1996; Stubhaug et al., 1997). This may be due to the opioid-sparing effect of ketamine. However, when low-dose ketamine is administered to healthy volunteers, incidence of nausea and vomiting appears to be greater than that reported in the clinical setting (Krystal et al., 1998; Sethna et al., 1998).

Urinary retention was found to be less common in patients using a PCA device administering a mixture of morphine and ketamine compared with PCA-morphine alone (Javery et al., 1996). Similar results were obtained when a continuous subcutaneous ketamine infusion was compared with a continuous subcutaneous morphine infusion (Bhattacharya et al., 1994).

There is no evidence that ketamine delays gastric emptying or gastro-coecal transit time (Grant et al., 1981; Freye and Knufermann, 1994).

\section{Psychotomimetic effects and impairment in cognitive functioning}

Disturbing emergence reactions (e.g. hallucinations, bad dreams) have limited the clinical usefulness of ketamine. The incidence varies from 5\% to greater than $30 \%$ (White et al., 1982) after high dose ketamine anesthesia. Several factors associated with psychotomimetic effects include age, sex, subjects who normally dream or have a history of psychopathology, high doses of ketamine $(>2 \mathrm{mg} / \mathrm{kg}$, i.v.) and rapid intravenous administration ( $>40 \mathrm{mg} / \mathrm{min}$ ) (White et al., 1982).

Six studies have examined the effects of low-dose ketamine administered to healthy volunteers (Table 8). Only one study was specifically designed to assess the effects of low dose ketamine on cognitive functioning and experimentally induced pain (Sethna et al., 1998). In the remaining five studies ketamine was administered to evaluate the psychiatric effects of NMDA receptor antagonism. Taken together, the results of these studies suggest that i.v. low-dose ketamine given at an infusion rate $<2.5 \mu \mathrm{g} / \mathrm{kg}$ per min (estimated plasma levels: $<50 \mathrm{ng} / \mathrm{ml}$ ) does not cause hallucinations (Krystal et al., 1994; 1998) or impairment of cognitive functioning (Krystal et al., 1994; Sethna et al., 1998). Other adverse effects such as a sense of intoxication, dizziness, blurred vision, itching or nausea and vomiting occur more commonly but the incidence of these adverse effects does not appear to differ from that of opioids (Sethna et al., 1998). At higher doses and plasma levels (200 $\mathrm{ng} / \mathrm{ml}$ ), incidence of cognitive and memory impairments, psychiatric symptoms, illusory experiences and other adverse effects increases (Krystal et al., 1994; 1998; Adler et al., 1998; Bowdle et al., 1998; Sethna et al., 1998).

In contrast to the research on healthy volunteers, studies of the effects of low-dose ketamine on perception, cognition and memory functioning in the acute postoperative setting have not been conducted. However, most trials do report the 


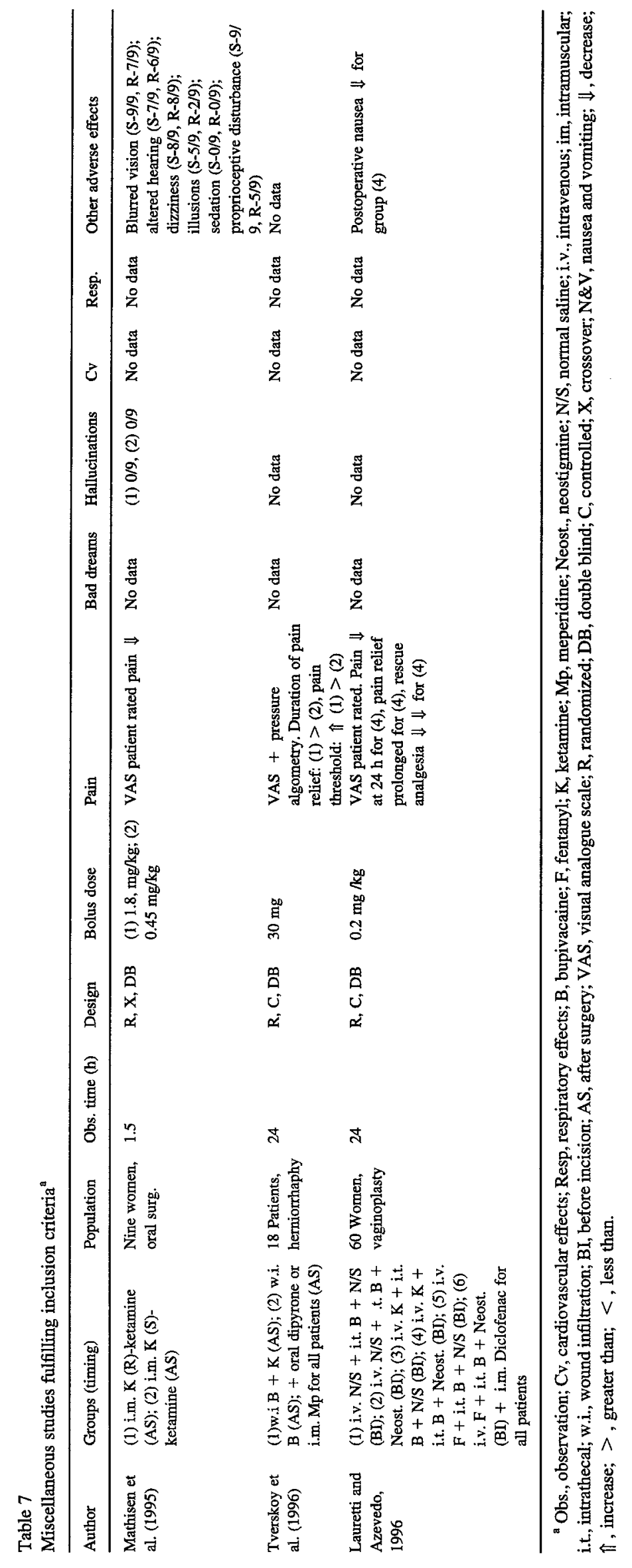




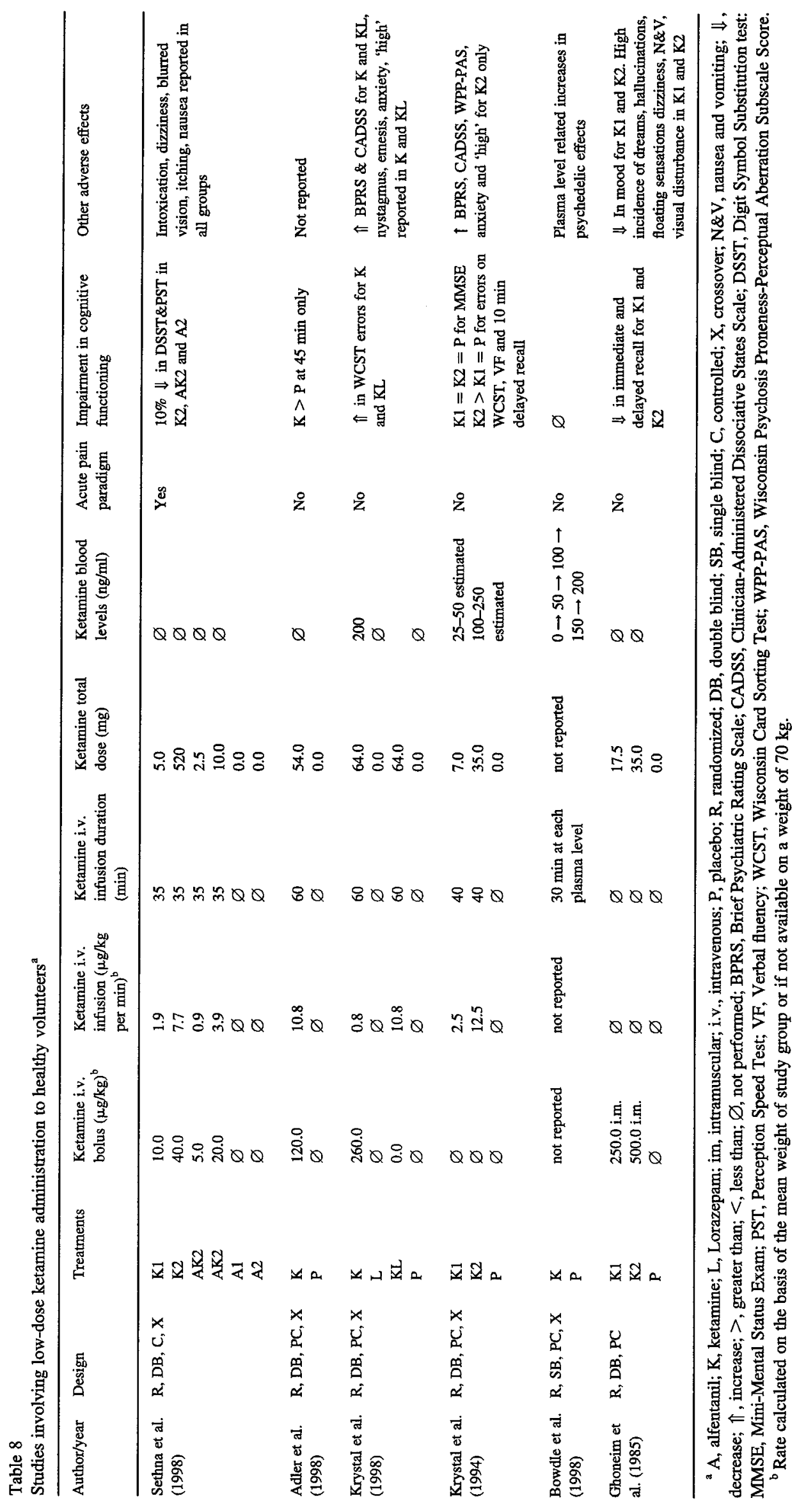


presence or absence of adverse effects including alterations in perception. These are described as 'floating in space' (Joachimsson et al., 1986; Maurset et al., 1989) or as a 'feeling of unreality' (Ito and Ichiyanagi, 1974), are reported infrequently, and occur in the high end of the low-dose range. The incidence of bad dreams or hallucinations is low or equals that of opioids (Dich-Nielsen et al., 1992). However, in two studies by the same research group, a total of 5 of 85 patients had severe enough psychotomimetic effects to require benzodiazepines or to be withdrawn from the study (Wong et al., 1996; Wong et al., 1997).

Taken together, in the clinical postoperative setting, the pharmacologic profile of adverse effects of low-dose ketamine appears to be less worrisome than that of opioids or NSAIDs. The incidence of psychotomimetic effects and cognitive impairment is negligible at doses less than 2.5 $\mu \mathrm{g} / \mathrm{kg}$ per.min i.v. and increases with higher doses. Within limits, and under appropriate monitoring, low-dose ketamine can be used safely either by itself or as an adjunct to traditional opioid analgesic therapy in the management of postoperative pain.

\section{Conclusions and recommendations}

Despite the many studies examining the use of ketamine in the treatment of acute postoperative pain, most are difficult to interpret due to fundamental problems with design, methods or statistical treatment of data. The following conclusions and recommendations are based only on studies that are randomized, prospective, double-blind, controlled and employ pain rating measures.

Low-dose ketamine as the sole analgesic agent reduces pain significantly using the following routes: i.m., s.c. and i.v. However a number of qualifications apply: i.m. ketamine may be suitable for short-term use only, and i.v. ketamine appears to provide satisfactory pain relief only at the upper end of the low-dose range $(1 \mathrm{mg} / \mathrm{kg}$ ) with an increased risk of psychotomimetic adverse effects. For certain clinical conditions (e.g. asthma, allergies) taking the risk-benefit relationship into consideration, ketamine (i.m., s.c., i.v.) might provide an alternative to conventional opioid analgesia (Jahangir et al., 1993).

There is little evidence that epidurally administered lowdose ketamine by itself provides effective postoperative analgesia, which is in line with recent findings in a rat model for postoperative pain (Zahn and Brennan, 1998). However, since both the preservative itself (Malinovsky et al., 1993) and preservative-free (Yaksh, 1996) ketamine may be associated with spinal toxicity it is recommended that ketamine not be injected intraspinally in humans.

There is a growing body of evidence that low-dose ketamine may play an important role in postoperative pain management when used as an adjunct to local anesthetics, opioids, or other analgesic agents. Duration of analgesia is increased when ketamine is added to a local anesthetic solu- tion for wound infiltration (Tverskoy et al., 1996). Ketamine in combination with opioids, either i.v. (continuous infusion, PCA) or epidurally, not only reduces opioid consumption but also prolongs and improves analgesia (Joachimsson et al., 1986; Javery et al., 1996; Wong et al., 1996; Stubhaug et al., 1997). This has also been observed after addition of low-dose i.v. ketamine to i.t. bupivacaine and neostigmine (Joachimsson et al., 1986; Javery et al., 1996; Wong et al., 1996; Stubhaug et al., 1997). The concept of 'balanced analgesia' (Dahl et al., 1990) merits attention (Dickenson, 1993), given the limits of opioid analgesia (Kehlet et al., 1996).

Pharmacological studies suggest that synergistic analgesic effects can be achieved by adding low-dose ketamine to opioids with the consequence of low-adverse effect liability (Hance et al., 1989; Chapman and Dickenson, 1992; Honore et al., 1996). However, a recent study of healthy volunteers found an additive, but not a synergistic, effect of ketamine and alfentanil. (Sethna et al., 1998). An additive effect is most likely a result of the combination of presynaptic opioid inhibition reducing afferent transmission by diminished transmitter release, and postsynaptic NMDA blockade which reduces wind up and central sensitization (Dickenson, 1994). A second mechanism underlying reduced opioid consumption might be the role of the NMDA receptor in the development of morphine tolerance. Recent observations suggest that the development of hyperalgesia and morphine tolerance are closely related and based on common neural substrates and intracellular events (Trujillo and Akil, 1994; Mao et al., 1995). Thus, the effects of low-dose ketamine at the NMDA receptor should not be considered 'analgesic' in the traditional sense of the term, but rather 'anti-hyperalgesic', 'anti-allodynic' and possibly 'tolerance-protective'.

The potential of low-dose ketamine may lie in its complementary and synergistic effects when combined with other analgesic agents (Dickenson, 1993; Yaksh, 1996). In this context, the concerns about the use of ketamine in postoperative pain management (Hirota and Lambert, 1996) need reconsideration. As one of the two clinically available NMDA receptor antagonists, ketamine may provide clinicians with a tool to improve postoperative pain management and to reduce opioid related adverse effects.

Results of studies evaluating efficacy of preemptive ketamine are promising and consistent with the pharmacology and the physiological importance of NMDA receptors outlined earlier. However, further well designed studies are required before any final conclusion can be drawn. Taken together, the role of ketamine in the treatment of postoperative pain remains controversial. On its own, ketamine remains a rescue drug for situations in which other analgesics are contraindicated. However, as an adjunct in combination with opioids or local anesthetics, low-dose ketamine, especially in the 'sub-psychotomimetic' range (blood concentration $<50 \mathrm{ng} / \mathrm{ml}$ ), may have an important role to play in the management of postoperative pain.

Further research is required in the following areas: (a) 
dose-finding studies for ketamine as an adjunct to opioids and local anesthetics (b) efficacy and optimal route of administration (intravenous vs. epidural vs. spinal) (c) the role of $\mathrm{S}(+)$-ketamine (d) the influence of ketamine on long-term outcome such as chronic pain (e) long-term physical and chemical stability of mixtures containing ketamine (f) spinal toxicity of ketamine and (g) effects of lowdose ketamine on cognitive and memory functioning after surgery.

Future studies should be carefully designed and whenever possible, conducted in a randomized, double-blind, controlled fashion. Pain should be rated by the patient using a reliable and valid pain scale (e.g. VAS). Rescue medication should be preferably administered using PCA. Outcomes other than pain and analgesic use (e.g., adverse effects, duration of hospital stay and cost -benefit analysis) should be included whenever possible.

\section{Acknowledgements}

This work was supported by a Medical Research Council of Canada (MRC) Scholarship Award and grants from the MRC (\#MT-12052) and NIH-NINDS (\#NS35480) to Joel Katz.

\section{References}

Abdel-Ghaffar ME, Abdulatif MA, al-Ghamdi A, Mowafi H, Anwar A. Epidural ketamine reduces post-operative epidural PCA consumption of fentanyl/bupivacaine. Can J Anaesth 1998;45:103-109.

Abrams R, Morrison JE, Villasenor A, Hencmann D, Da Fonseca M, Mueller W. Safety and effectiveness of intranasal administration of sedative medications (ketamine, midazolam, or sufentanil) for urgent brief pediatric dental procedures. Anesth Prog 1993;40:63-66.

Adler CM, Goldberg TE, Malhotra AK, Pickar D, Breier A. Effects of ketamine on thought disorder, working memory and semantic memory in healthy volunteers. Biol Psychiatry 1998;43:811-816.

Alderson PJ, Lerman J. Oral premedication for paediatric ambulatory anaesthesia: a comparison of midazolam and ketamine. Can J Anaesth 1994;41:221-226.

Alfonzo-Echeverri EC, Berg JH, Wild TW, Glass NL. Oral ketamine for pediatric outpatient dental surgery sedation. Pediatr Dent 1993;15:182_185.

Amiot JF, Bouju P, Palacci JH. Use of ketamine for epidural anesthesia (letter). Presse Med 1985;14:228.

Austin TR. Ketamine on demand for postoperative analgesia (letter). Anaesthesia 1981;36:214.

Bhattacharya A, Gurnani A, Sharma PK, Sethi AK. Subcutaneous infusion of ketamine and morphine for relief of postoperative pain: a doubleblind comparative study. Ann Acad Med Singapore 1994;23:456-459.

Borgbjerg FM, Svensson BA, Frigast C, Gordh Jr T. Histopathology after repeated intrathecal injections of preservative-free ketamine in the rabbit: a light and electron microscopic examination. Anesth Analg 1994;79:105-111.

Bourke DL, Malit LA, Smith TC. Respiratory interactions of ketamine and morphine. Anesthesiology 1987;66:153-156.

Bowdle TA, Radant AD, Cowley DS, Kharasch ED, Strassman RJ, RoyByrne PP. Psychedelic effects of ketamine in healthy volunteers: relationship to steady-state plasma concentrations. Anesthesiology $1998 ; 88: 82-88$.
Bristow A, Orlikowski C. Subcutaneous ketamine analgesia: postoperative analgesia using subcutaneous infusions of ketamine and morphine (see comments). Ann R Coll Surg Engl 1989;71:64-66.

Brock-Utne JG, Kallichurum S, Mankowitz E, Maharaj RJ, Downing JW. Intrathecal ketamine with preservative - histological effects on spinal nerve roots of baboons. S Afr Med J 1982;61:440-441.

Calvey TN. Isomerism and anaesthetic drugs. Acta Anaesthesiol Scand 1995;106:83-90.

Chapman V, Dickenson AH. The combination of NMDA antagonism and morphine produces profound antinociception in the rat dorsal horn. Brain Res 1992;573:321-323.

Chia YY, Liu K, Liu YC, Chang HC, Wong CS. Adding ketamine in a multimodal patient-controlled epidural regimen reduces postoperative pain and analgesic consumption. Anesth Analg 1998;86:1245-1249.

Choe H, Choi YS, Kim YH, Ko SH, Choi HG, Han YJ, Song HS. Epidural morphine plus ketamine for upper abdominal surgery: improved analgesia from preincisional versus postincisional administration. Anesth Analg 1997;84:560-563.

Chung SK, Chan KH, Lee TY, Lui PW, Yang MW, Huang YL, Liu K, Wu $\mathrm{CI}, \mathrm{Fu}$ YP. Epidural ketamine for postoperative pain relief. Ma Tsui Hsueh Tsa Chi 1986;24:251-257.

Cioaca R, Canavea I. Oral transmucosal ketamine: an effective premedication in children. Paediatr Anaesth 1996;6:361-365.

Clausen L, Sinclair DM, Van Hasselt CH. Intravenous ketamine for postoperative analgesia. S Afr Med J 1975;49:1437-1440.

Clements JA, Nimmo WS. Pharmacokinetics and analgesic effect of ketamine in man. Br J Anaesth 1981;53:27-30.

Coderre TJ, Katz J, Vaccarino AL, Melzack R. Contribution of central neuroplasticity to patholgical pain: review of clinical and experimenatal evidence. Pain 1993;52:259-285.

Cohen ML, Trevor AJ. On the cerebral accumulation of ketamine and the relationship between metabolism of the drug and its pharmacological effects. J Pharmacol Exp Ther 1974;189:351-358.

Cook B, Grubb DJ, Aldridge LA, Doyle E. Comparison of the effects of adrenaline, clonidine and ketamine on the duration of caudal analgesia produced by bupivacaine in children. Br J Anaesth 1995;75:698-701.

Corssen G, Domino EF. Dissociative anesthesia: further pharmacologic studies and first clinical experience with the phencyclidine derivative CI-581. Anesth Analg 1966;45:29-40.

Dahl JB, Kehlet $H$. The value of pre-emptive analgesia in the treatment of postoperative pain (see comments). Br J Anaesth 1993;70:434-439.

Dahl JB, Rosenberg J, Dirkes WE, Mogensen T, Kehlet H. Prevention of postoperative pain by balanced analgesia. $\mathrm{Br} J$ Anaesth 1990;64:518520 .

Dich-Nielsen JO, Svendsen LB, Berthelsen P. Intramuscular low-dose ketamine versus pethidine for postoperative pain treatment after thoracic surgery. Acta Anaesthesiol Scand 1992;36:583-587.

Dick W, Knoche E, Grundlach G, Klein I. Clinical experimental studies of postoperative infusion analgesia. Anaesthesist 1983;32:272-278.

Dickenson AH. Combination therapy in analgesia; seeking synergy. Curr Opin Anaesthesiol 1993;6:861-865.

Dickenson AH. NMDA receptor antagonists as analgesics. In: Fields HL, Liebeskind JC, editors. Pharmacological Approaches to the Treatment of Chronic Pain: New Concepts and Critical Issues, 1. Seattle: IASP Press, 1994. pp. 173.

Dickenson AH. Spinal cord pharmacology of pain. Br J Anaesth 1995;75:193-200.

Edwards ND, Fletcher A, Cole JR, Peacock JE. Combined infusions of morphine and ketamine for postoperative pain in elderly patients. Anaesthesia 1993;48:124-127.

Finck AD, Ngai SH. Opiate receptor mediation of ketamine analgesia. Anesthesiology 1982;56:291-297.

Findlow D, Aldridge LM, Doyle E. Comparison of caudal block using bupivacaine and ketamine with ilioinguinal nerve block for orchidopexy in children. Anaesthesia 1997;52:1110-1113.

Forestner JE. Postoperative ketamine analgesia in children: efficacy and safety after halothane anesthesia. South Med J 1988;81:1253-1257. 
Foster AC, Fagg GE. Neurobiology. Taking apart NMDA receptors. Nature 1987;329:395-396.

Freye E, Knufermann V. No inhibition of intestinal motility following ketamine-midazolam anesthesia. A comparison of anesthesia with enflurane and fentanyl/midazolam. Anaesthesist 1994;43:87-91.

Fu ES, Miguel R, Scharf JE. Preemptive ketamine decreases postoperative narcotic requirements in patients undergoing abdominal surgery. Anesth Analg 1997;84:1086-1090.

Ghoneim MM, Hinrichs JV, Mewaldt SP, Petersen RC. Ketamine: behavioral effects of subanesthetic doses. J Clin Psychopharmacol 1985;5:70-77.

Grant IS, Nimmo WS, Clements JA. Lack of effect of ketamine analgesia on gastric emptying in man. Br $J$ Anaesth 1981;53:1321-1323.

Gurnani A, Sharma PK, Rautela RS, Bhattacharya A. Analgesia for acute musculoskeletal trauma: low-dose subcutaneous infusion of ketamine. Anaesth Intensive Care 1996;24:32-36.

Hagelin A, Lundberg D. Ketamine for postoperative analgesia after upper abdominal surgery. Clin Ther 1981;4:229-233.

Hance AJ, Winters WD, Quam DD, Benthuysen JL, Cadd GG. Catalepsy induced by combinations of ketamine and morphine: potentiation, antagonism, tolerance and cross-tolerance in the rat. Neuropharmacology 1989;28:109-116.

Hartvig P, Larsson E, Joachimsson PO. Postoperative analgesia and sedation following pediatric cardiac surgery using a constant infusion of ketamine. J Cardiothorac Vasc Anesth 1993;7:148-153.

Hirota K, Lambert DG. Ketamine: its mechanism(s) of action and unusual clinical uses (editorial). Br J Anaesth 1996;77:441-444.

Hollman GA, Perloff WH. Efficacy of oral ketamine for providing sedation and analgesia to children requiring laceration repair (letter). Pediatr Emerg Care 1995;11:399.

Honore P, Chapman V, Buritova J, Besson JM. Concomitant administration of morphine and an $N$-methyl-D-aspartate receptor antagonist profoundly reduces inflammatory evoked spinal c-Fos expression. Anesthesiology 1996;85:150-160.

Hustveit $\mathrm{O}$, Maurset A, Oye I. Interaction of the chiral forms of ketamine with opioid, phencyclidine, sigma and muscarinic receptors. Pharmacol Toxicol 1995;77:355-359.

Ilkjaer S, Petersen KL, Brennum J, Wernberg M, Dahl JB. Effect of systemic $N$-methyl-D-aspartate receptor antagonist (ketamine) on primary and secondary hyperalgesia in humans. Br. J. Anaesth 1996;76:829-834.

Islas JA, Astorga J, Laredo M. Epidural ketamine for control of postoperative pain. Anesth Analg 1985;64:1161-1162.

Ito $\mathrm{Y}$, Ichiyanagi $\mathrm{K}$. Post-operative pain relief with ketamine infusion Anaesthesia 1974;29:222-226.

Ivankovich AD, McCarthy RJ. Epidural ketamine for control of postoperative pain: two comments (letter). Anesth Analg 1986;65:989-990.

Jahangir SM, Islam F, Aziz L. Ketamine infusion for postoperative analgesia in asthmatics: a comparison with intermittent meperidine. Anesth Analg 1993;76:45-49

Javery KB, Ussery TW, Steger HG, Colclough GW. Comparison of morphine and morphine with ketamine for postoperative analgesia Can J Anaesth 1996;43:212-215.

Jiang KR, Ho WM, Tsai YJ, Tseng F, Tso HS. Pulmonary function and analgesic effect after epidural ketamine for postoperative pain relief. Ma Tsui Hsueh Tsa Chi 1988;26:9-14.

Joachimsson PO, Hedstrand U, Eklund A. Low-dose ketamine infusion for analgesia during postoperative ventilator treatment. Acta Anaesthesiol Scand 1986;30:697-702.

Katz J, Kavanagh BP, Sandler AN, Nierenberg H, Boylan JF, Friedlander $\mathrm{M}$, Shaw BF. Preemptive analgesia. Clinical evidence of neuroplasticity contributing to postoperative pain (see comments). Anesthesiology 1992;77:439-446.

Katz J. Pre-emptive analgesia: evidence, current status and future directions. Eur J Anaesthesiol 1995;10:8-13.

Kawana Y, Sato H, Shimada H, Fujita N, Ueda Y, Hayashi A, Araki Y. Epidural ketamine for postoperative pain relief after gynecologic opera- tions: a double-blind study and comparison with epidural morphine. Anesth Analg 1987;66:735-738.

Kehlet H, Rung GW, Callesen T. Postoperative opioid analgesia: time for a reconsideration?. J Clin Anesth 1996;8:441-445.

Knoche E, Dick W, Bowdler I, Gundlach G. Clinical experimental studies of postoperative infusion analgesia. Clin Ther 1983;5:585-594.

Krystal JH, Karper LP, Seibyl JP, Freeman GK, Delaney R, Bremner JD, Heninger GR, Bowers Jr MB, Charney DS. Subanesthetic effects of the noncompetitive NMDA antagonist, ketamine, in humans. Psychotomimetic, perceptual, cognitive and neuroendocrine responses. Arch Gen Psychiatry 1994;51:199-214.

Krystal JH, Karper LP, Bennett A, D'Souza DC, Abi-Dargham A, Morrissey K, Abi-Saab D, Bremner JD, Bowers Jr MB, Suckow RF, Stetson P, Heninger GR, Charney DS. Interactive effects of subanesthetic ketamine and subhypnotic lorazepam in humans. Psychopharmacology 1998;135:213-229.

Kucuk N, Kizilkaya M, Tokdemir M. Preoperative epidural ketamine does not have a postoperative opioid sparing effect. Anesth Analg 1998;87:103-106.

Lauretti GR, Azevedo VM. Intravenous ketamine or fentanyl prolongs postoperative analgesia after intrathecal neostigmine. Anesth Analg 1996;83:766-770.

Louon A, Reddy VG. Nasal midazolam and ketamine for paediatric sedation during computerised tomography. Acta Anaesthesiol Scand $1994 ; 38: 259-261$

Maduska AL, Hajghassemali M. Arterial blood gases in mothers and infants during ketamine anesthesia for vaginal delivery. Anesth Analg 1978;57:121-123.

Malinovsky JM, Lepage JY, Cozian A, Mussini JM, Pinaudt M, Souron R. Is ketamine or its preservative responsible for neurotoxicity in the rabbit? (see comments). Anesthesiology 1993;78:109-115.

Mankowitz E, Brock-Utne JG, Cosnett JE, Green-Thompson R. Epidural ketamine. A preliminary report. S Afr Med J 1982;61:441-442.

Mao J, Price DD, Mayer DJ. Mechanisms of hyperalgesia and morphine tolerance: a current view of their possible interactions. Pain 1995;62:259-274

Marietta MP, Way WL, Castagnoli Jr N, Trevor AJ. On the pharmacology of the ketamine enantiomorphs in the rat. J Pharmacol Exp Ther 1977;202:157-165.

Mathisen LC, Skjelbred P, Skoglund LA, Oye I. Effect of ketamine, an NMDA receptor inhibitor, in acute and chronic orofacial pain. Pain 1995;61:215-220.

Maurset A, Skoglund LA, Hustveit O, Oye I. Comparison of ketamine and pethidine in experimental and postoperative pain. Pain 1989;36:37-41.

Murray WB, Yankelowitz SM, le Roux M, Bester HF. Prevention of posttonsillectomy pain with analgesic doses of ketamine. S Afr Med. J 1987;72:839-842.

Naguib M, Adu-Gyamfi Y, Absood GH, Farag H, Gyasi HK. Epidural ketamine for postoperative analgesia. Can Anaesth Soc J 1986;33:1621.

Naguib M, Adu-Gyamfi Y. Epidural ketamine for postoperative analgesia (letter). Anesth Analg 1988;67:798-799.

Naguib M, Sharif AM, Seraj M, el Gammal M, Dawlatly AA. Ketamine for caudal analgesia in children: comparison with caudal bupivacaine. $\mathrm{Br} \mathrm{J}$ Anaesth 1991;67:559-564.

Ngan Kee WD, Khaw KS, Ma ML, Mainland PA, Gin T. Postoperative analgesic requirement after Cesarian section: A comparison of anesthetic induction with ketamine or thiopental. Anesth Analg 1997;85:1294-1298.

Orser BA, Pennefather PS, MacDonald JF. Multiple mechanisms of ketamine blockade of $N$-methyl-D-aspartate receptors. Anesthesiology 1997;86:903-917.

Owen H, Reekie RM, Clements JA, Watson R, Nimmo WS. Analgesia from morphine and ketamine. A comparison of infusions of morphine and ketamine for postoperative analgesia. Anaesthesia 1987;42:1051-1056.

Oye I, Paulsen O, Maurset A. Effects of ketamine on sensory perception: 
evidence for a role of $N$-methyl-D-aspartate receptors. J Pharmacol Exp Ther 1992;260:1209-1213.

Parkhouse J, Marriott G. Postoperative analgesia with ketamine and pethidine. Anaesthesia 1977;32:285-289.

Peat SJ, Bras P, Hanna MH. A double-blind comparison of epidural ketamine and diamorphine for postoperative analgesia. Anaesthesia 1989;44:555-558

Pedraz JL, Lanao JM, Calvo MB, Muriel C, Hernandez-Arbeiza J, Dominguez-Gil A. Pharmacokinetic and clinical evaluation of ketamine administered by i.v. and epidural routes. Int J Clin Pharmacol Ther Toxicol 1987;25:77-80.

Ravat F, Dorne R, Baechle JP, Beaulaton A, Lenoir B, Leroy P, Palmier B. Epidural ketamine or morphine for postoperative analgesia. Anesthesiology 1987;66:819-822.

Reich DL, Silvay G. Ketamine: an update on the first twenty-five years of clinical experience. Can J Anaesth 1989;36:186-197.

Rogawski MA. Therapeutic potential of excitatory amino acid antagonists: channel blockers and 2,3-benzodiazepines. Trends Pharmacol Sci 1993;14:325-331.

Roytblat L, Korotkoruchko A, Katz J, Glazer M, Greemberg L, Fisher A. Postoperative pain: the effect of low-dose ketamine in addition to general anesthesia (see comments). Anesth Analg 1993;77:1161-1165.

Ryder S, Way WL, Trevor AJ. Comparative pharmacology of the optical isomers of ketamine in mice. Eur J Pharmacol 1978;49:15-23.

Sadove MS, Shulman M, Hatano S, Fevold N. Analgesic effects of ketamine administered in subdissociative doses. Anesth Analg 1971;50:452-457.

Scheller M, Bufler J, Hertle I, Schneck HJ, Franke C, Kochs E. Ketamine blocks currents through mammalian nicotinic acetylcholine receptor channels by interaction with both the open and the closed state. Anesth Analg 1996;83:830-836.

Schuttler J. $S-(+)$-ketamine. The beginning of a new ketamine era? (editorial; comment). Anaesthesist 1992;41:585-587.

Schwinn DA, Leslie JB, Watkins WD. Basic principles of pharmacology and anesthesia. In: Miller RD, editor. Anesthesia, 1. New York: Churchill Livingstone, 1994. pp. 46.

Semple D, Findlow D, Aldridge LM, Doyle E. The optimal dose of ketamine for caudal epidural blockade in children. Anaesthesia 1996;51:1170-1172.

Sethna NF, Liu M, Gracely R, Bennett GJ, Max MB. Analgesic and cognitive effects of intravenous ketamine-alfentanil combinations versus either drug alone after intradermal capsaicin in normal subjects. Anesth Analg 1998;86:1250-1256.

Silvay G. Ketamine. Mt Sinai J Med 1983;50:300-304.

Smith DJ, Pekoe GM, Martin LL, Coalgate B. The interaction of ketamine with the opiate receptor. Life Sci 1980;26:789-795.

Stevens CL. Belgium Pat. 634,208; corresponding to Parke Davis U.S. Pat. 3,254,124, , Merck Index, 12th 1963;:903.

Stubhaug A, Breivik H, Eide PK, Kreunen M, Foss A. Mapping of punctuate hyperalgesia around a surgical incision demonstrates that ketamine is a powerful suppressor of central sensitization to pain following surgery. Acta Anaesthesiol Scand 1997;41:1124-1132.

Trujillo KA, Akil H. Inhibition of opiate tolerance by non-competitive $N$ methyl-D-aspartate receptor antagonists. Brain Res 1994;633:178-188.
Tverskoy M, Oz Y, Isakson A, Finger J, Bradley Jr EL, Kissin I. Preemptive effect of fentanyl and ketamine on postoperative pain and wound hyperalgesia (see comments). Anesth Analg 1994;78:205-209.

Tverskoy M, Oren M, Vaskovich M, Dashkovsky I, Kissin I. Ketamine enhances local anesthetic and analgesic effects of bupivacaine by peripheral mechanism: a study in postoperative patients. Neurosci Lett 1996;215:5-8.

Van der Auwera D, Verborgh C, Camu F. Epidural ketamine for postoperative analgesia (letter). Anesth Analg 1987;66:1340.

Warner DL, Cabaret J, Velling D. Ketamine plus midazolam, a most effective paediatric oral premedicant. Paediatr Anaesth 1995;5:293-295.

Weir PS, Fee JP. Double-blind comparison of extradural block with three bupivacaine-ketamine mixtures in knee arthroplasty. $\mathrm{Br} \mathrm{J}$ Anaesth 1998;80:299-301.

Weksler N, Ovadia L, Muati G, Stav A. Nasal ketamine for paediatric premedication. Can J Anaesth 1993;40:119-121.

White PF, Ham J, Way WL, Trevor AJ. Pharmacology of ketamine isomers in surgical patients. Anesthesiology 1980;52:231-239.

White PF, Way WL, Trevor AJ. Ketamine - its pharmacology and therapeutic uses. Anesthesiology 1982;56:119-136.

White PF, Schuttler J, Shafer A, Stanski DR, Horai Y, Trevor AJ. Comparative pharmacology of the ketamine isomers. Studies in volunteers. $\mathrm{Br} \mathrm{J}$ Anaesth 1985;57:197-203.

Wilcox, G.L., Excitatory neurotransmitters and pain, The 6th World Congress on Pain, Adalaide, 1991

Wilder-Smith OH, Arendt-Nielsen L, Gaumann D, Tassonyi E, Rifat KR. Sensory changes and pain after abdominal hysterectomy: a comparison of anesthetic supplementation with fentanyl versus magnesium or ketamine. Anesth Analg 1998;86:95-101.

Willetts J, Balster RL, Leander JD. The behavioral pharmacology of NMDA receptor antagonists (see comments). Trends Pharmacol Sci 1990;11:423-428.

Wong CS, Liaw WJ, Tung CS, Su YF, Ho ST. Ketamine potentiates analgesic effect of morphine in postoperative epidural pain control (see comments). Reg Anesth 1996;21:534-541.

Wong CS, Lu CC, Cherng CH, Ho ST. Pre-emptive analgesia with ketamine, morphine and epidural lidocaine prior to total knee replacement. Can J Anaesth 1997;44:31-37.

Woolf CJ, Chong MS. Preemptive analgesia - treating postoperative pain by preventing the establishment of central sensitization. Anesth Analg 1993;77:362-379.

Yaksh TL. Epidural ketamine: a useful, mechanistically novel adjuvant for epidural morphine? (editorial; comment). Reg Anesth 1996;21:508513.

Yamamura T, Harada K, Okamura A, Kemmotsu O. Is the site of action of ketamine anesthesia the $N$-methyl-D-aspartate receptor?. Anesthesiology 1990;72:704-710.

Yanli Y, Eren A. The effect of extradural ketamine on onset time and sensory block in extradural anaesthesia with bupivacaine. Anaesthesia 1996;51:84-86.

Zahn PK, Brennan TJ. Lack of effect of intrathecally administered $\mathrm{N}$ methyl-D-aspartate receptor antagonists in a rat model for postoperative pain. Anesthesiology 1998;88:143-156. 